International Journal of Agriculture, Environment and Bioresearch

Vol. 5, No. 05; 2020

ISSN: $2456-8643$

\title{
VULNERABILITY FACTORS OF AGRICULTURAL PRODUCTION GROUPS TO CLIMATE CHANGE IN THE MUNICIPALITIES OF SAVE AND GLAZOUE
}

\author{
Hervé Dègla KOUMASSI* \\ Pierre Pagney Laboratory, Climate, Water, Ecosystems and Development (LACEEDE) \\ Institute of Geography, Regional Planning and Environment (IGATE) \\ University of Abomey Calavi (UAC) \\ Cocou Parfait BLALOGOE \\ Laboratory for Environmental Geoscience and Applications (LaGEA) \\ National Superior School of Public Works (ENSTP) \\ National University of Science and Technology, Engineering and Mathematics (UNSTIM) \\ https://doi.org/10.35410/IJAEB.2020.5553
}

\begin{abstract}
In rural communities, roles and responsibilities devolved to men and women; their differences in access to resources and in their control over those resources define women's vulnerability to climate change. The objective of this study is to analyze the factors of vulnerability of agricultural production groups to climate change.

The methodological approach used consisted of collecting data, processing and analyzing the results. A total of 17 agricultural groups were surveyed in the two Communes. The choice of groups was based on several criteria. Focus groups were organized during which the vulnerability profiles of the groups were identified in a participatory manner.

From the analysis of the results, three fundamental factors of vulnerability were identified by the women's agricultural groups. The position of the production site in relation to raw materials, in fact, $62.7 \%$ of the respondents use the lowlands for production, $38.6 \%$ use the banks and $13.9 \%$ of the respondents use the edges of the courses. water for agricultural production. The second factor is access to financial resources due to the lack of collateral availability. The third factor lies in the difficulties of accessing value-added activities and markets.
\end{abstract}

Keywords: vulnerabilities, agricultural women's groups, Communes of Savè and Glazoué, climate change.

\section{INTRODUCTION}

Climate change is one of the greatest challenges of the 21st century. From the findings of the Intergovernmental Panel on Climate Change (IPCC), it is clear that populations who are already the most vulnerable and marginalized will be the most affected. Climate change has had enormous consequences on the ecosystem and on the living conditions of populations. Their 
effects vary by region, generation, age, social class, income group and gender.

Both men and women who work in natural resource sectors, such as agriculture, will feel the effects to varying degrees (ILO, 2008). It is increasingly evident that women are more vulnerable than men, in large part because they represent the majority of the world's poor and are more dependent on threatened natural resources. The difference between men and women is also notable in terms of their roles, responsibilities, decision-making, access to land and natural resources, opportunities and needs (Elasha, O. 2008)) .

Of the 1.3 billion people living in conditions of poverty, $70 \%$ are women. In urban areas, $40 \%$ of the poorest households have a woman as head of household. While women play a key role in global food production (50-80\%), they own less than $10 \%$ of the land (IUCN, 2007)

The difference between men and women is also notable with regard to their roles, responsibilities, decision-making, access to land and natural resources, opportunities and needs (Elasha, O.2008). But women are not only the victims of climate change, they can also act actively and effectively and promote methods of adaptation and mitigation.

In recent years, more and more vulnerability analyzes have been carried out in order to identify sites particularly vulnerable to climate change and to provide elements for adaptation and development programming at the local, national levels. and regional. The conduct of vulnerability analyzes has taken on particular importance in the context of national adaptation plans (NAPs). Thus, adaptation initiatives should include the identification of the gender-specific impacts of climate change and the implementation of measures to respond to them, in particular in areas related to water, food security, agriculture, energy, health, disaster management and conflict. It is also important to consider important gender issues related to access to resources, including credit, extension and training services, information and technology (UNDP, 2009). In this context that the present study was undertaken. It aims to analyze the vulnerability factors of women's groups in the Communes of Savè and Glazoué.

\section{PRESENTATION OF THE STUDY ENVIRONMENT}

The Communes of Glazoué and Savè are located between parallels $7^{\circ} 57^{\prime}$ 'and $8^{\circ} 19^{\prime}$ north latitude and between $2^{\circ} 05$ ' and $2^{\circ} 49$ east longitude. They have respectively ten (10) districts including forty-eight (48) villages and city districts on the one hand and 08 districts including 13 city districts and 25 villages on the other hand. The relief has the shape of a crystalline peneplain resting on a Precambrian base. This peneplain which occupies almost the entire surface of the Municipality is marked by the presence of hills in place. 
Vol. 5, No. 05; 2020

ISSN: $2456-8643$

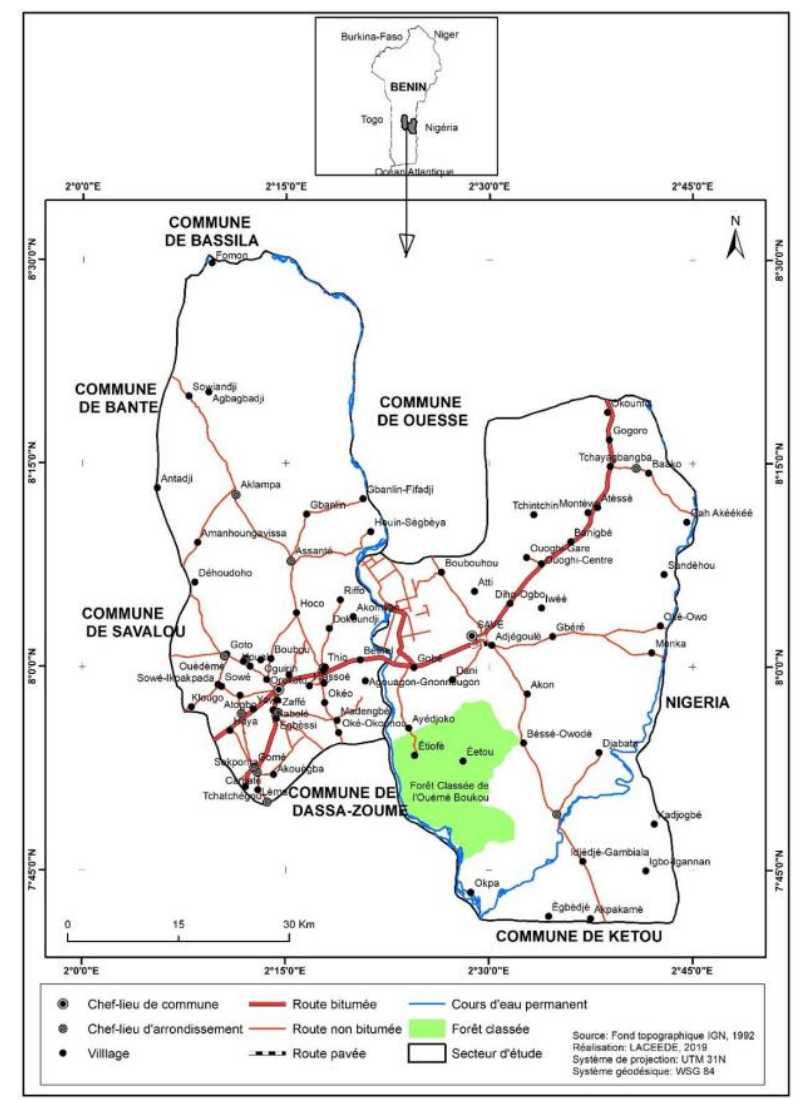

Figure 1: Geographical and administrative situation of Savè and Glazoué

The Communes of Savè and Glazoué are located in the climatic transition zone between the subequatorial in the South and the Sudanese in the North. This climate transition zone experiences two pluviometric optima in July and September separated by the recession in August (Boko, 1988).

The dominant soil formations are in these municipalities are:

Tropical ferruginous soils, hydromorphic soils, ferralitic soils. They characterize the granitegneissic basement more or less concreted and leached presenting low-sloping shells Aïfan (1993) and Yabi (2002);

ferralitic soils are in low proportion. They have a sandy to sandy-clay texture on the surface, becoming clay-sandy at depth. The particulate structure at the surface to massive at depth, sometimes more or less rich in ferruginous concretion. The color is reddish brown. They are permeable and their drainage is normal (UNDP, 2007);

Hydromorphic soils or Vertisols are clayey, thick and black soils, and are located at the edge of valleys and in depressions. 
These different plant formations are dotted with fields and fallows characterized by species such as: Elaeis guineesis, Mangiferaindica, Borassus aethiopum, Anacardium occidental, Tectona grandis, ParkiaBiglobosa, etc. (Adam and Boko 1993). The teak (Tectona grandis) and cashew (Anacardium occidental) plantations, which are currently experiencing remarkable expansion, form anthropogenic vegetation.

\section{METHODOLOGICAL APPROACH}

The methodological approach used in this study revolves around data collection, processing and analysis of the results.

The data used are among others, statistics on the number of groups in the Communes, information on the activities of groups. Their fields of activity, the date of creation and the location of these. Two main data collection tools developed as part of this study concern questionnaires sent to groups and interview guides sent to resource persons and authorities at various levels. Table I shows the distribution of the groups surveyed in the communes of Savè and Glazoué.

Table I: Distribution of groups surveyed in the Commune of Savèet de Glazoué.

\begin{tabular}{|c|c|c|c|c|c|}
\hline Groupings & $\begin{array}{l}\text { Creation } \\
\text { date }\end{array}$ & $\begin{array}{l}\text { Number of } \\
\text { members }\end{array}$ & Specification area & Locality & Boroughs \\
\hline Ifêtayo & 2008 & 22 & $\begin{array}{l}\text { Production agricole en } \\
\text { générale }\end{array}$ & Alafia & Kaboua \\
\hline $\begin{array}{l}\text { Egbè o } \\
\text { èkoshé }\end{array}$ & 2014 & 20 & Production du soja & Atchakpa & Offè \\
\hline Tibonan 2 & 2016 & 20 & Production de coton & $\begin{array}{l}\text { Igbodja } \\
\text { barrière } \\
\text { somba }\end{array}$ & Bessé \\
\hline Tiwinti & 2015 & 22 & production du soja & Igboyoko & Adido \\
\hline Ababori & 2012 & 31 & production de riz & Boubouhou & Okpara \\
\hline Féré si shè & 2015 & 18 & $\begin{array}{l}\text { Transformation de } \\
\text { manioc en divers } \\
\text { dérivés }\end{array}$ & Diho & Sakin \\
\hline Agbè loba & 2014 & 25 & Production de Soja & Akon & Plateau \\
\hline Ifèdon & 2012 & 18 & $\begin{array}{l}\text { Transformation } \\
\text { d'arachide }\end{array}$ & Akparè & Boni \\
\hline Azognon & 2015 & 24 & $\begin{array}{l}\text { Production agricole et } \\
\text { maraichage }\end{array}$ & Hoco & Thio \\
\hline $\begin{array}{l}\text { La terre ne } \\
\text { ment jamais }\end{array}$ & 2015 & 16 & Maraichage & Hoco & Thio \\
\hline Sènan & 2014 & 23 & Apiculture & Hoco & Thio \\
\hline Katchitchè & 1999 & 26 & $\begin{array}{lr}\text { Production } & \text { et } \\
\text { transformation } & \text { des } \\
\text { produits agricoles } & \\
\end{array}$ & Bethel & Thio \\
\hline
\end{tabular}


International Journal of Agriculture, Environment and Bioresearch

Vol. 5, No. 05; 2020

ISSN: $2456-8643$

\begin{tabular}{|c|c|c|c|c|c|}
\hline Ifèdou & 2008 & 18 & $\begin{array}{l}\text { Production } \\
\text { transformation du soja } \\
\text { en fromage }\end{array}$ & Rifo & Thio \\
\hline Kalifè & 2015 & 30 & $\begin{array}{l}\text { Production et l'étuvage } \\
\text { du riz }\end{array}$ & Yawa & Kpakpaza \\
\hline $\begin{array}{l}\text { Bo doun a } \\
\text { غ́kodjé }\end{array}$ & 2009 & 17 & la production du soja & Sowé & Kpakpaza \\
\hline Ishédoun & 2009 & 22 & Production du soja & Magoumi & Magoumi \\
\hline IfÉdoun & 2008 & 17 & $\begin{array}{l}\text { Production du riz et } \\
\text { transformation de soja } \\
\text { en fromage }\end{array}$ & Zaffé & Zaffé \\
\hline
\end{tabular}

In total, 17 women's agricultural groups were surveyed in the two Communes. The choice of the two municipalities is based on two fundamental criteria, namely:

Be a female agricultural group or have more than $2 / 3$ of women in its workforce

Have a seniority of at least five years

Have its main activity in the agricultural sector (production, processing, marketing, breeding)

After the questionnaires were collected from the team leaders of each group of investigators, a first processing of the completed forms consisted of the coding of the variables and the development of the input mask in the SPSS software (Statistical Package for the Social Science) version 16.0. The data collected was entered into this software. In addition to the questionnaire information, they are made up of metadata identifying the number of the questionnaire and the date of the interview. These fields were cleaned after use to keep only the information from the questionnaire. A third process consisted of checking for duplicates. For this, the initially cleaned database was implemented in a MYSQL database management system such as Microsoft Access. No duplicates were observed. After clearing the database, the various analyzes were carried out. This method made it possible to extract the different percentages and to illustrate them by graphs with Microsoft Excel.

\section{RESULTS}

The vulnerability of women's groups to climate change depends on several factors. These factors arise from the fact that climate change is not gender neutral and has different effects depending on sex.

\section{1- Production sites of groups}

The production or installation sites of the groups depends on several criteria. They can be the proximity of raw materials, sources of production etc. Figure 2 shows the production sites of the groups in the target Communes of the project 
Vol. 5, No. 05; 2020

ISSN: $2456-8643$

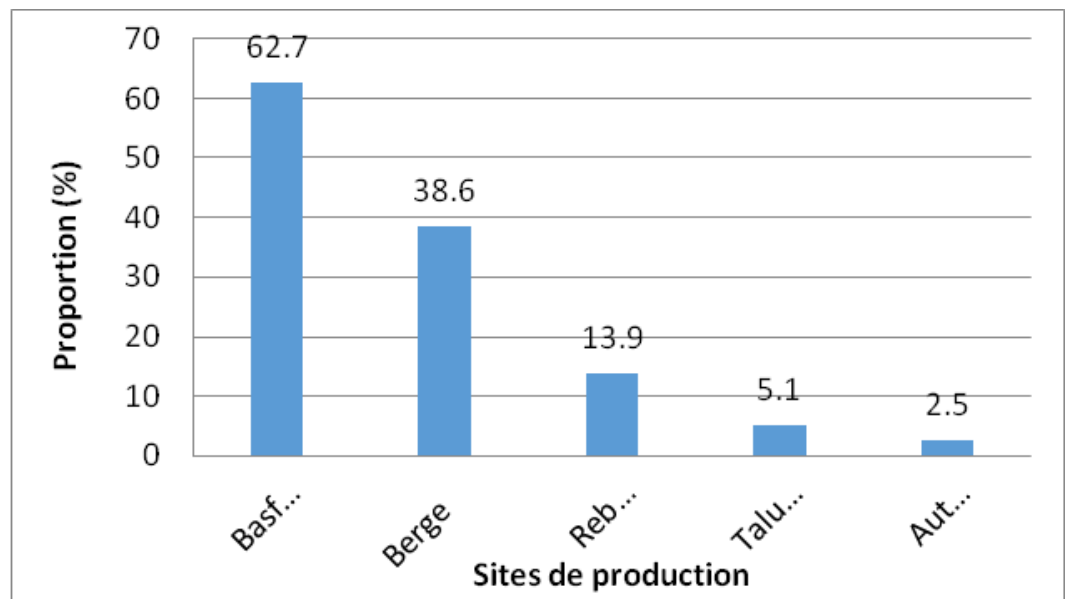

Figure 2: Production site of the groups

Source: fieldwork, 2019

The analysis in Figure 2 shows that $62.7 \%$ of respondents use the lowlands for production, $38.6 \%$ use the banks and $13.9 \%$ of the respondents use the edges of rivers for agricultural production. The installation of groups on these sites increases their vulnerabilities to climatic extremes, especially floods.

\section{2- Limited access to financial resources}

In general, women's groups have poor access to credit. The problem of access to credit generally arises for groups, but it is more accentuated for women's groups, which often do not have the necessary guarantees required by traditional banks.

Financial institutions claim that the risk presented by this category of activities is too high. This explains why they are turning to decentralized financial systems. Here too, we realize that although most often constituting the majority of the membership of savings and credit mutuals, the volume of credit they receive is less than that of large cooperatives. In addition, the loans are sometimes of a derisory amount and with a short repayment period, which does not allow them to make large-scale investments. There are other local arrangements that result in the establishment of tontines and other forms of solidarity funds, but these arrangements do not allow for substantial investments in agricultural production tools and inputs.

\subsection{Difficulties in accessing value-added activities and markets}

Women's agricultural groups focus mainly on production and marketing, ignoring certain links in the value chain that are important in ensuring sustainable development of this vital sector for rural women. In fact, agricultural production does not take into account the inputs necessary to 
improve production, nor the disposal, processing or conservation infrastructures, nor packaging requirements, and even less market needs (consumers). . In addition, the absence of norms and standards demanded by consumer markets as well as the weakness of quality control sometimes exclude products from peasant agriculture from certain markets. It should be noted that the agricultural feeder roads constitute one of the major obstacles affecting the agricultural sector; the products are often removed by women on foot or by bicycle, over long distances, which generally affects their presentation and quality. Losses in production are also linked to the low level of post-harvest support following the non-existence or insufficient packaging and storage infrastructure. Finally, the low level of processing forces the women's agricultural groups to sell their production at a low price to intermediaries who will carry out the transformation, subsequently reselling the processed product to the consumer in the required form. This limits the profit margin accruing to the woman farmer who is excluded from the realization of the surplus value. Finally, the absence of standards governing the activity as well as the weakness of quality control excludes products from peasant agriculture from certain markets.

\section{CONCLUSION}

In the agricultural sector, agricultural women's groups in rural areas are the main producers of staple foods. Crops in these areas are very exposed to climatic risks. Inequalities in access to information and resources as well as imbalances in decision-making power expose these groupings to the effects of climate risks. In order to effectively reduce vulnerability, programs to adapt to change These various vulnerability factors must be integrated in order to develop the resilience of groups to the various shocks and pressures to which they are exposed.

\section{REFERENCE}

1- ILO, 2008. Report of the Committee on Employment and Social Policy, Impacts of Climate Change on Labor Market Dynamics, fourth item on the agenda, governing body, , 303rd session (Geneva), p. 2.

2- Osman-Elasha, 2008 "Gender and Climate Change in the ArabRegion", Arab Women's Organization p. 44.

3- Aguilar, L., 2008. "Is thereaconnectionbetweengender and climate change?", International Union for the Conservation of Nature (IUCN), Office of the Principal Advisor for Gender Equality.

4- Rena, Ravinder et N. Narayana (2007) «GenderEmpowerment in Africa: An Analysis of Women Participation in EritreanEconomy», New Delhi: International Journal of Women, Social Justice and 4- Rena, Ravinder and N. Narayana (2007) "GenderEmpowerment in Africa: An Analysis of Women Participation in EritreanEconomy", New Delhi: International Journal of Women, Social Justice and HumanRights, vol. 2. N \& deg; 2, p. 221-237 (Serials publication). 5- IUCN 2004 (a), "Climate Change and Disaster Mitigation: GenderMakes the Difference". Intergovernmental Panel on Climate Change, 2001. Climate change: consequences, adaptation and vulnerability, contribution of Working Group II to the Third Assessment Report of the IPCC. 
6- IUCN 2004 (b), "Energy: GenderMakes the Difference". Gender Action, 2008. Gender Action Link: Climate Change (Washington,

7- D.C.), http: //www.genderaction.org/images/Gender\%20Action\%20Link\%20-\%20Climate\%

Third World Congress of Women on Politics and Governance, 2008. Conference briefing and background paper, Manila, Philippines, October 19-22, www.capwip.org/3rdglobalcongress.htm

8- IUCN 2007, "Gender and Climate Change: Women as Agents of Change".

9- UNDP (2009): Resource Guide on Gender Equality and Climate Change, World Bank, 157 p. 